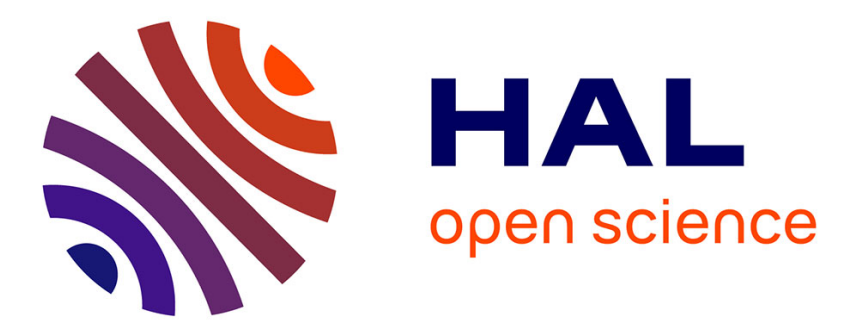

\title{
On the role of regular phonological variation in lexical access: Evidence from voice assimilation in French
}

\author{
Natalie D. Snoeren, Juan Seguí, Pierre Hallé
}

\section{To cite this version:}

Natalie D. Snoeren, Juan Seguí, Pierre Hallé. On the role of regular phonological variation in lexical access: Evidence from voice assimilation in French. Cognition, 2008, 2 (108), pp.B512-B521. 10.1016/j.cognition.2008.02.008 . halshs-00684074

\section{HAL Id: halshs-00684074 \\ https://shs.hal.science/halshs-00684074}

Submitted on 10 Apr 2012

HAL is a multi-disciplinary open access archive for the deposit and dissemination of scientific research documents, whether they are published or not. The documents may come from teaching and research institutions in France or abroad, or from public or private research centers.
L'archive ouverte pluridisciplinaire HAL, est destinée au dépôt et à la diffusion de documents scientifiques de niveau recherche, publiés ou non, émanant des établissements d'enseignement et de recherche français ou étrangers, des laboratoires publics ou privés. 
On the role of regular phonological variation in lexical access: Evidence from voice assimilation in French

\author{
Natalie D. Snoeren ${ }^{\mathrm{a}}$, Juan Seguí ${ }^{\mathrm{a}}$, and Pierre A. Halléab \\ ${ }^{a}$ Laboratoire de Psychologie et Neurosciences Cognitives \\ Université Paris Descartes, CNRS \\ ${ }^{\mathrm{b}}$ Laboratoire Phonétique et Phonologie, CNRS-Paris 3
}

Brief Article (3072 words)

Running head: Phonological variation and lexical access

\title{
Corresponding author:
}

Natalie D. Snoeren, now at the Department of Psychology,

University of York, Heslington, York, YO10 5DD, United Kingdom

E-mail address: n.snoeren@psych.york.ac.uk 


\begin{abstract}
The present study investigated whether lexical access is affected by a regular phonological variation in connected speech: voice assimilation in French. Two associative priming experiments were conducted to determine whether strongly assimilated, potentially ambiguous word forms activate the conceptual representation of the underlying word. Would the ambiguous word form [sud] (either assimilated soute 'hold' or soude 'soda') facilitate "bagage" 'luggage', which is semantically related to soute but not to soude? In Experiment 1, words in either canonical or strongly assimilated form were presented as primes. Both forms primed their related target to the same extent. Potential lexical ambiguity did not modulate priming effects. In Experiment 2, the primes such as assimilated soute pronounced [sud] used in Experiment 1 were replaced with primes such as soude canonically pronounced [sud]. No semantic priming effect was obtained with these primes. Therefore, the effect observed for assimilated forms in Experiment 1 cannot be due to overall phonological proximity between canonical and assimilated forms. We propose that listeners must recover the intended words behind the assimilated forms through the exploitation of the remaining traces of the underlying form, however subtle these traces may be.
\end{abstract}


One of the fundamental issues in the auditory word recognition domain pertains to the observation that listeners can recognize words in spite of numerous variations that are present in the speech signal. The perceptual processing of regular surface variations such as phonological assimilation has received a lot of attention in the literature (Lahiri \& Marslen-Wilson, 1991; Gaskell \& Marslen-Wilson, 1996, 1998, 2001; Gow, 2001, 2002, 2003; Gow \& Im, 2004; Coenen, Zwitserlood, \& Bölte, 2001; Gumnior, Zwitserlood, \& Bölte, 2005; Mitterer \& Blomert, 2003; Snoeren, Seguí, \& Hallé, 2008). Assimilation refers to the process by which a speech segment becomes more like an adjacent segment in terms of one or more phonetic features. Since the explicit conditioning environment (i.e. the adjacent segment) licenses the phonological change, some authors have argued that listeners use phonological context to infer a particular surface form (e.g., Gaskell \& Marslen-Wilson, 1996, 1998). This view was recently challenged by some empirical studies presenting evidence that the assimilated speech signal generally contains traces of the underlying segment (Nolan, 1992; Gow, 2001; 2002). In a previous paper, we provided an acoustic-phonetic description of voice assimilation in French, which may occur when two consonants of different voicing are adjacent (Snoeren, Hallé, \& Seguí, 2006). For instance, the word-final /p/ in jupe (“dress") tends to become voiced when followed by a voiced consonant (e.g., [3yb] in jupe grise). Our acoustic measurements showed that voice assimilation in French can be graded and preserve fine-grained acoustic traces of the underlying form. Importantly, it has been shown that the listener can exploit these traces to access the underlying word form (Gow, 2002, 2003).

More recently (Snoeren et al., 2008), we investigated the role of phonological context in the perception of assimilated speech in French, using a cross-modal identity priming paradigm. In Experiment 1, in which primes were presented without the assimilating context, a significantly larger priming effect was obtained for the unassimilated (canonical) than assimilated form of the prime words, suggesting that these priming effects reflected different degrees of activation of phonological representation. Norris, Cutler, McQueen, and Butterfield 
(2006: 149) noted that, "Identity priming does not necessarily imply that conceptual representations have been activated..." At least, it is conceivable that assimilated word forms mainly activate phonological rather than more abstract lexical representations.

In this study, we directly tested for the possibility that even strongly assimilated forms activate lexical-conceptual representations, by using a cross-modal associative priming paradigm. Importantly, we used naturally (as opposed to deliberately) assimilated words as auditory primes. Ambiguous assimilated forms ( $\mathrm{such}_{\mathrm{as}}\left[\mathrm{su}_{\mathrm{d}}^{\mathrm{t}}\right]$, from either soute or soude) might be less efficient than unambiguous forms (such as $\left[3 \mathrm{y}^{\mathrm{p}} \mathrm{b}\right]$, jupe being the sole possible underlying word) in priming an associated target, conceivably due to the competition of the non-intended word. Nevertheless, the acoustic traces of the intended word in the speech signal might be sufficient to recover that word, and even ambiguous assimilated forms might prime a target associated to the intended word. In Experiment 1, we test for the associative priming effects for ambiguous and unambiguous assimilated forms.

\section{Experiment 1}

\section{Method}

\section{Participants}

Seventy students at the Psychology Department of Paris-Descartes University, native speakers of French, participated in Experiment 1. Thirty-six students (34 women and two men, mean age 24 years) were assigned to the canonical condition, and 34 participants (30 women and four men, mean age 21 years) to the assimilated condition (see below).

\section{Design and Materials}

Twenty-four French monosyllabic nouns ending with a voiceless stop were selected as experimental items: twelve words had a minimal pair for final stop voicing (e.g., soute) and 12 words had none (e.g., jupe). Words with a voiceless rather than voiced final stop were used, 
because previous research showed that the former are more prone to voice assimilation than the latter. Other lexical characteristics are summarized in Table 1.

The experimental noun items were inserted in noun phrases (determinant + noun + adjective). To obtain the canonical and assimilated versions of each noun, its right context either licensed voice assimilation (e.g., une soute bondée), or not (e.g., une soute pleine). The assimilating and the assimilated consonants always had a different place of articulation in order to avoid gemination. A female non-naïve native speaker of Parisian French was asked to produce the noun phrases in a fluid fashion, without pause between words (to increase the likelihood of voice assimilation). Each noun was excised from its noun-phrase context (care was taken to avoid auditory clicks in the excised stimuli). Peak acoustic intensity was equalized across all stimuli. The excised words served as auditory primes. A native French speaker, expert in the field of auditory speech perception, was asked to categorize the word-final consonant of the stimuli. For all the assimilated words, final consonants were categorized as voiced (e.g., the final stop of voice-assimilated soute was perceived as /d/, not /t//). Acoustically, the assimilated stops all had a fully voiced closure: the "voicing ratio" (Snoeren et al., 2006) was 100\%.

A free association procedure was used to select targets semantically associated to primes. Fifty-eight participants were asked to report the first word that came to their mind upon written presentation of each of the experimental items. For each item, the most frequent response across participants (39\% in average) was retained as the associated word to be used as target. The same primes were used in the related and unrelated prime-target pairs by rotating the prime-target associations. For instance, the prime gratte was associated to GUITARE in the related condition and to BAGAGE in the unrelated condition.

Forty-eight filler word-word prime-target pairs were constructed. For 24 of them, prime and target were semantically associated (e.g., crabe $-M E R$ ); they were not for the 24 others (e.g., larve - LOISIR). The semantic associates were obtained from Ferrand and Alario's (1998) association tables (mean association rate 27\%). Finally, 72 filler word-nonword prime-target 
pairs were added. For 24 of those, the nonword target was derived from a word semantically related to the prime (e.g., ciel-ESLACE: the nonword eslace is derived from espace 'space', related to ciel 'sky'); these targets are, as it were, "pseudo-related" to their prime. These 24 "pseudo-related" prime-target pairs were inserted to avoid a bias toward positive response for pairs in which a semantic relationship might be detected. The primes in the filler prime-target pairs were matched for frequency with the primes in the experimental pairs. Like the experimental primes, the filler primes were recorded within spoken noun-phrases, then excised.

To summarize, the materials consisted of 24 experimental prime-target pairs (12 with potentially ambiguous primes, 12 with unambiguous primes), 48 filler word-word pairs (half of which with semantically related prime and target), and 72 filler word-nonword pairs (24 of which pseudo-related).

Given the limited number of French words in the potentially ambiguous category, all of them were presented to each subject in either their canonical or assimilated form. That is, Form of realization (canonical vs. assimilated) was a between-subject factor: all the experimental primes were presented in their canonical form (e.g., [sut] for soute) to one group of participants, and in their assimilated form (e.g., [sud] for soute) to the other group. Semantic relation (related vs. unrelated) was counterbalanced across subjects within each group so that each subject saw any given target only once.

\section{Procedure}

Prime words were presented auditorily through Sennheiser headphones. At the offset of the prime, the target was displayed on a screen for three seconds. The participant was required to press the "yes" button if the target was a French word, and the "no" button if it was not. Reaction times were measured from the offset of the prime. The DMDX software (Forster \& Forster, 2003) was used to run the experiment. In addition to the experimental and filler trials, 10 practice trials were presented in a training phase. The test phase begun with two warm-up trials. The total duration of the experiment was about 15 minutes. 


\section{Results and Discussion}

The data of five participants in the canonical condition and three in the assimilated condition were not retained, due to technical problems. The overall error rate was $4.2 \%$. Response times under $300 \mathrm{~ms}$ or above $1200 \mathrm{~ms}$ (less than 1.5\%) were excluded from the RT analyses. Table 2 shows the RT and error data in each condition. ANOVAs were conducted on the RT data with Form of realization (canonical vs. assimilated) as a between-subject factor, and Word type (with vs. without a voicing counterpart) and Semantic relation (related vs. unrelated) as within-subject factors.

Only Semantic relation had a significant effect, $F_{1}(1,60)=17.09, p<.001$ (by-subject), $F_{2}(1,22)=7.47, p<.05$ (by-item); it did not interact with the other factors. RTs were shorter in the related than unrelated condition (496 vs. $519 \mathrm{~ms}$ ), and this held for both the canonical and assimilated conditions (canonical: $t(30)=2.41, p<.05$; assimilated: $t(30)=3.61, p<.01$ ).

The results of Experiment 1 showed a classic semantic priming effect. Targets following a semantically related prime (soute - BAGAGE) were responded to faster than those following an unrelated prime (gratte - BAGAGE), regardless of Word type or Form of realization. The size of the priming effect was relatively small (21 and $26 \mathrm{~ms}$ in the canonical and assimilated condition, respectively), as is usually found in associative cross-modal priming experiments (e.g., Moss, Ostrin, Tyler, \& Marslen-Wilson, 1995).

The results suggest that ambiguous, strongly assimilated forms still activate the lexicalconceptual representation of the intended underlying word. However, before we can attribute the priming effect to the presence of acoustic traces in the assimilated form, we need to rule out an alternative explanation: phonological proximity of canonical and assimilated forms. Previous studies have shown that spoken word recognition is relatively tolerant for deviations from canonical forms (e.g., Bölte \& Coenen, 2000; Connine, Blasko, \& Titone, 1993). If an assimilated form (e.g., [sud] for soute) and a similar though canonically realized form (e.g., 
[sud] for soude) are processed in the same fashion by the perceptual system due to their phonological proximity, then soude (canonical form [sud]) should prime $B A G A G E$ as much as the assimilated form prime of soute [sud]. After all, the critical consonant in the voiceassimilated form of soute was perceived as /d/ by a French native speaker. Alternatively, if the canonical form prime of soude does not prime $B A G A G E$ as efficiently as the assimilated form of soute, this would suggest that the perceptual system distinguishes between two versions that are almost identical in their surface form. In the latter case, the semantic priming effect that was obtained in Experiment 1 could only be attributed to the presence of fine-grained acoustic traces of voicelessness in the assimilated form [sud] of soute. Of course, these considerations only concern the words that have a lexical counterpart in terms of final-stop voicing. A second experiment was conducted to test for the possibility that canonical, unassimilated soude primes $B A G A G E$.

\section{Experiment 2}

\section{Method}

Participants

Thirty-five native speakers of French (30 female and 5 male students, mean age 22 years), students at Paris-Descartes University, participated in Experiment 2.

\section{Design and Materials}

Twelve experimental words such as soude, the voiced counterparts of the words such as soute used in Experiment 1 served as auditory primes. They were recorded in a non-assimilatory context (e.g., une soude brute). Each of them was associated to the same target as that used for its voiceless counterpart in Experiment 1 (e.g., the target for soude was $B A G A G E$ ). Words were excised from context using the same procedure as in Experiment 1. The remaining materials were the same as in the canonical condition of Experiment 1. Only the unassimilated forms of 
the prime words were used. Hence, there was no "Form of realization" factor in this experiment. The materials were recorded by the same speaker as in Experiment 1.

\section{Procedure}

The experimental procedure was identical to that in Experiment 1.

\section{Results and Discussion}

The data of one participant were not retained due to technical problems. The overall error rate was $2.33 \%$. As in Experiment 1 , RTs outside the [300, $1200 \mathrm{~ms}]$ range $(0.86 \%)$ were excluded from analyses.

The experimental primes (e.g., soude) did not significantly facilitate their target (e.g., "bagage"). For the experimental prime-target pairs, RTs to target were 530 and $525 \mathrm{~ms}$ for related (soude - BAGAGE) and unrelated (grade - BAGAGE) pairs, respectively. This difference did not reach significance, $F_{s}<1$. The absence of priming for pairs such as soude$B A G A G E$ could not be attributed to a general insensitivity to semantic relationship in this experiment. Indeed, RTs were shorter for the related than unrelated word-word filler pairs (522 vs. $550 \mathrm{~ms}), t(33)=5.26, p<.001$, showing a clear semantic priming effect.

In a separate analysis, we directly compared the outcomes of Experiments 1 and 2 to assess priming effects to the same targets (e.g., BAGAGE) preceded by assimilated primes (soute pronounced [sud]) and by canonical primes (soude pronounced [sud]). A two-way ANOVA was conducted with Form of realization (assimilated - Expt.1 vs. canonical - Expt. 2) and Semantic relation (related vs. unrelated) as main factors. No significant effect was observed for the two main factors, but their interaction was significant, $F_{1}(1,63)=4.09, p<.05, F_{2}(1,11)$ $=6.17, p<.05$. This interaction shows that primes whose surface forms are very close may be processed differently, depending on the speaker's intention (e.g., soude vs. soute, both realized [sud]). The surface form [sud] facilitates $B A G A G E$ only when the speaker's intended word is soute. But how different is this form from the canonical form of soude [sud]? Detailed acoustic 
analyses revealed that all differences pointed to stronger cues to voicedness in canonical soude than in assimilated soute. In particular, preceding vowel duration, a classic cue to obstruent voicing (Peterson \& Lehiste, 1960), was longer for canonical soude (82 vs. 73 ms, one-tailed ttest, $t(11)=2.10, p<.05)$. The assimilated stops tended to be "less voiced" than the plain voiced stops on other dimensions as well: longer closure duration (57 vs. $54 \mathrm{~ms}$ ), higher F0 at preceding vowel offset (231 vs. $224 \mathrm{~Hz})$, and lower intensity of the occlusion (67.4 vs. $69.1 \mathrm{~dB}$, one-tailed t-test, $t(11)=2.05, p<.05)$. These acoustic analyses suggest that, at least for strongly assimilated words, the speaker's intention is reflected by fine-grained secondary acoustic cues that are not captured by the voicing ratio index (see Snoeren et al., 2006).

\section{General Discussion}

The purpose of the present study was to investigate whether the assimilated form of a word presented in isolation activates its lexical-conceptual representation. We thus compared the semantic priming effects induced by canonical and (strongly) assimilated word forms. Half of the assimilated primes were potentially ambiguous (e.g., [sud] is a realization of either soute or soude), the other half were not ([3yb] can only be a realization of jupe). In Experiment 1, semantic priming effects were observed, regardless of form of realization, and potential ambiguity. In Experiment 2, we used as primes the voiced counterparts of the words such as soute used in Experiment 1 (hence, soude for soute), associated with the same targets. No priming effects obtained for these primes. That is, soude did not prime $B A G A G E$ related to soute.

That assimilated word forms induce semantic priming effects suggests a lexicalconceptual locus for these effects. This finding is in line with previous studies showing that lexical access is not necessarily impaired by regular surface variations in the speech signal, (Deelman \& Connine, 2001; Sumner \& Samuel, 2005). The semantic priming effects found in 
Experiment 1 also held for ambiguous assimilated forms, compatible with two words differing in the voicing of their final stop. In this case, lexical competition does not block the activation of the lexical-conceptual representation of the intended, underlying word.

In the present study, the priming effects for canonical and assimilated word forms had comparable magnitudes ( 21 vs. $26 \mathrm{~ms})$. These results contrast with those obtained in our previous study using identity priming (Snoeren et al., 2008). In that study, assimilated word forms induced significantly less priming than canonical forms (Experiment 1: 32 vs. $95 \mathrm{~ms}$ ), suggesting that identity priming effects mainly reflected the activation of phonological representations. In the present study, using semantic priming, comparable effects were found for canonical and assimilated forms, suggesting a lexical-conceptual locus of these effects. Taken together, the different outcomes for cross-modal identity priming and associative priming indicate that the two paradigms are differentially sensitive to phonological and lexical levels of representation.

As we pointed out earlier, the assimilated word forms used as primes in Experiment 1 were strongly assimilated, as judged by an expert speech scientist and as shown by acoustic measurements, and therefore clearly differed from the canonical forms. It is thus surprising that they gave rise to semantic priming effects of very similar magnitude. A possible account in terms of general tolerance for phonological mismatch (cf. Connine et al., 1993), tested in Experiment 2, does not explain the outcome of Experiment 2: soude [sud] did not prime $B A G A G E$ as soute realized [sud] did. The explanation we propose is that the speech signal retains traces of the underlying voicing of intended words (Goldrick \& Blumstein, 2006). Listeners would exploit these traces to access abstract lexical representations, however subtle they are. It is therefore quite remarkable that the speech comprehension system is successful to access the speaker's intentions on the basis of such fine-grained acoustic detail. 


\section{References}

Bölte, J., \& Coenen, E. (2000). Domato primes paprika: Mismatching pseudowords activate semantic and phonological representations. In Proceedings of the SWAP Conference (pp. 59-62). Nijmegen, The Netherlands.

Coenen, E. Zwitserlood, P. \& Bölte, J. (2001). Variation and assimilation in German: Consequences for lexical access and representation. Language and Cognitive Processes, $16(5-6), 535-564$.

Connine, C.M., Blasko, D.G., \& Titone, D. (1993). Do the beginnings of spoken words have a special status in auditory word recognition? Journal of Memory and Language, 32, 193210.

Deelman, T., \& Connine, C.M. (2001). Missing information in spoken word recognition: nonreleased stop consonants. Journal of Experimental Psychology: Human Perception \& Performance, 27(3), 656-663.

Ferrand, L., \& Alario, F.-X., (1998). Normes d'association verbales pour 366 d'objets concrets. L’Année Psychologique, 98, 659-709.

Forster, K.I., \& Forster, J.C. (2003). DMDX: A Windows display program with millisecond accuracy. Behavior Research Methods, Instruments, \& Computers, 35, 16-124.

Gaskell, M.G., \& Marslen-Wilson, W.D. (1996). Phonological variation and inference in lexical access. Journal of Experimental Psychology: Human Perception \& Performance, 22(1), 144-158.

Gaskell, M.G. \& Marslen-Wilson, W.D. (1998). Mechanisms of phonological inference in speech perception. Journal of Experimental Psychology: Human Perception \& Performance, 24(2), 380-396.

Gaskell, M.G. \& Marslen-Wilson, W.D. (2001). Lexical ambiguity and spoken word recognition: Bridging the gap. Journal of Memory and Language, 44, 325-349. 
Goldrick, M., \& Blumstein, S.E. (2006). Cascading activation from phonological planning to articulatory processes: Evidence from tongue twisters. Language and Cognitive Processes, 21(6), 649-683.

Gow, D.W. (2001). Assimilation and anticipation in continuous spoken word recognition. Journal of Memory and Language, 24, 133-159.

Gow, D.W. (2002). Does English coronal place assimilation create lexical ambiguity? Journal of Experimental Psychology: Human Perception \& Performance, 28, 163-179.

Gow, D.W. (2003). Feature parsing: Feature cue mapping in spoken word recognition. Perception \& Psychophysics, 65(4), 575-590.

Gow, D.W. \& Im, A.M. (2004). A cross-linguistic examination of assimilation context effects. Journal of Memory and Language, 51, 279-296.

Gumnior, H., Zwitserlood, P., \& Bölte, J. (2005). Assimilation in existing and novel compounds. Language and Cognitive Processes, 20(3), 465-488.

Lahiri, A. \& Marslen-Wilson, W.D. (1991). The mental representation of lexical form: a phonological approach to the recognition lexicon. Cognition, 38(3), 245-294.

Mitterer, H., \& Blomert, L. (2003). Coping with phonological assimilation in speech perception: Evidence for early compensation. Perception \& Psychophysics, 65(6), 956-969.

Moss, H.E., Ostrin, R.K., Tyler, L.K., \& Marslen-Wilson, W.D. (1995). Accessing different types of lexical semantic information: Evidence from priming. Journal of Experimental Psychology: Learning, Memory, \& Cognition, 21(4), 863-883.

Nolan, F. (1992). The descriptive role of segments: Evidence from assimilation. In G.J. Docherty \& D.R. Ladd (Eds.), Laboratory Phonology II: Gesture, segment, prosody, (pp. 261-280). Cambridge: Cambridge University Press.

Norris, D. Cutler, A., McQueen, J.M., \& Butterfield, S. (2006). Phonological and conceptual activation in speech comprehension. Cognitive Psychology, 53, 146-193. 
Peterson, G. I., \& Lehiste, I. (1960). Duration of syllabic nuclei in English. Journal of the Acoustical Society of America, 32, 693-703.

Snoeren, N.D., Hallé, P.A. \& Seguí, J. (2006). A voice for the voiceless: Production and perception of assimilated speech in French. Journal of Phonetics, 34(2), 241-268.

Snoeren, N.D., Seguí, J. \& Hallé, P.A. (2008). Perceptual processing of partially and fully assimilated words in French. Journal of Experimental Psychology: Human Perception \& Performance, 34(1), 193-204.

Sumner, M., \& Samuel, A.G. (2005). Perception and representation of regular variation: The case of final /t/. Journal of Memory and Language, 52, 322-338. 


\section{Appendix}

(A) Experiment 1: primes (with the context in which they were produced) and associated targets; for potentially ambiguous primes, the voiced counterpart word is shown between parentheses.

\begin{tabular}{|c|c|c|}
\hline Canonical primes & Assimilated primes & Associated Target \\
\hline \multicolumn{3}{|l|}{ Potentially ambiguous } \\
\hline 1. Un black policier (blague) & Un black bourgeois & NOIR \\
\hline 2. Une trompe tendue (trombe) & Une trompe d'éléphant & ELEPHANT \\
\hline 3. Une gratte cassée (grade) & Une gratte blues & GUITARE \\
\hline 4. Une soute pleine (soude) & Une soute bondée & BAGAGE \\
\hline 5. Une jatte poreuse (jade) & Une jatte beurrée & LAIT \\
\hline 6. Un bec tordu (bègue) & Un bec droit & OISEAU \\
\hline 7. Un rite populaire (ride) & Un rite barbare & COUTUME \\
\hline 8. La dope coupée (daube) & La dope danoise & DROGUE \\
\hline 9. Le bock profond (bogue) & Le bock bavarois & BIERE \\
\hline 10. Une cote prometteuse (code) & Une cote boursière & CHIFFRE \\
\hline 11. Un bac professionnel (bague) & Un $b a c$ difficile & EXAMEN \\
\hline 12. Une rate cancéreuse (rade) & Une rate bileuse & FOIE \\
\hline \multicolumn{3}{|l|}{ Unambiguous } \\
\hline 1. Une coupe teintée & Une coupe dorée & CHEVEUX \\
\hline 2. Une jupe courte & Une jupe grise & ROBE \\
\hline 3. Une nappe carrée & Une nappe décolorée & TABLE \\
\hline 4. Une troupe théâtrale & Une troupe grotesque & THEATRE \\
\hline 5. Une grotte profonde & Une grotte bretonne & CAVERNE \\
\hline 6. Une lutte permanente & Une lutte guèrrière & COMBAT \\
\hline 7. Une note pertinente & Une note grave & MUSIQUE \\
\hline 8. Une faute criminelle & Une faute grave & ERREUR \\
\hline 9. La nuque tordue & La nuque dégagée & $\mathrm{COU}$ \\
\hline 10. Un choc thermique & Un choc brutal & ACCIDENT \\
\hline 11. Une brique tombée & Une brique brisée & MAISON \\
\hline 12. La plaque tectonique & La plaque dentaire & EGOUT \\
\hline
\end{tabular}


(B) Experiment 2: primes (with the context in which they were produced) and associated targets; these primes are the voiced counterparts of the potentially ambiguous primes of Expt. 1 (see Appendix A).

\begin{tabular}{ll}
\hline Voiced final-stop primes & Associated targets \\
\hline Une blague belge & NOIR \\
Une trombe d'eau & ELEPHANT \\
Une grade militaire & GUITARE \\
Une soude brute & BAGAGE \\
Une jade magique & LAIT \\
Un bègue gêné & OISEAU \\
Une ride volcanique & COUTUME \\
Une daube monumentale & DROGUE \\
Une bague métallique & EXAMEN \\
Une bogue verte & BIERE \\
Un code valide & CHIFFRE \\
Un rade branchouille & FOIE \\
\hline
\end{tabular}


Author Note

This research was supported by a Ministère de l'Education Nationale, de la Recherche, et de la Technologie (MENRT) doctoral fellowship to the first author. We thank Gareth Gaskell for the stimulating discussions about the content of this paper, as well as three anonymous reviewers who provided insightful comments on an earlier version of the manuscript. 
Table 1. Lexical properties of the experimental primes used in Experiment 1. "Amb" stands for words potentially ambiguous after assimilation (e.g., soute may be confounded with soude if realized $[\mathrm{sud}]$ ) and "Unamb" for unambiguous words (e.g., jupe has no voiced counterpart in French); log frequency; number of phonological neighbors (nphon); number of phonological neighbors by substitution of the word-final consonant (FC-phon); number of more frequent word-final consonant phonological neighbors (HF-phon); mean association rate for the associated prime-target pairs (AR); target log frequency (tgt-freq).

\begin{tabular}{lcccccc}
\hline Type & log freq & nphon & FC-phon & HF-phon & AR & tgt-freq \\
\hline Amb & 0.59 & 24.18 & 9.67 & 4.63 & $41.3 \%$ & 1.31 \\
Unamb & 1.42 & 16.75 & 6.17 & 0.92 & $36.6 \%$ & 1.7 \\
\hline
\end{tabular}


Table 2. Mean RTs in ms (SD between parentheses) and error rates in \% to target in Experiment 1 for the canonical and assimilated conditions according to Semantic relation (related or unrelated) and Word type (potentially ambiguous or not).

\begin{tabular}{llll}
\multicolumn{2}{c}{ "Canonical condition" } & \multicolumn{2}{c}{ "Assimilated condition" } \\
Related & Unrelated & Related & Unrelated \\
{$[$ sut]- BAGAGE } & {$[$ grat]- BAGAGE } & {$[$ sud]-BAGAGE } & {$[$ grad]-BAGAGE } \\
$501(61)$ & $521(85)$ & $484(56)$ & $513(85)$ \\
1.6 & 3.8 & 4.3 & 3.2 \\
{$[3 y$ ] $]-$ ROBE } & {$[\mathrm{kup}]-$ ROBE } & {$[3 \mathrm{yb}]-\mathrm{ROBE}$} & {$[\mathrm{kub}]-\mathrm{ROBE}$} \\
$509(73)$ & $530(89)$ & $490(57)$ & $511(72)$ \\
3.8 & 5.4 & 4.8 & 7
\end{tabular}

